\title{
SZABÓ JÁNOS ÉLETÚTJA*
}

\author{
KURUTZNÉ KOVÁCS MÁRTA
}

Amikor arra a feladatra készültem, hogy Szabó János gazdag életútját ismertessem, és a dokumentumokat gyüjtögettem össze a családtól, kollégáktól, barátoktól, világosan kirajzolódott előttem, miként szőtték át az ő életét is, mint mindannyiunkét, XX. századi történelmünk különösen mozgalmas és ellentmondásos szálai. Eszembe jutottak Csonka Pálnak, egyetemünk legendás professzorának szavai, amelyek 90. születésnapján, ugyanebben a teremben hangzottak el néhány évvel ezelőtt. A következőket mondotta: „Hosszú életem a teljes magyar történelem csaknem egytizedét teszi ki, és ebben az egytizedben, századunkban minden előfordult, ami a történelemben egyáltalán előfordulhat. Voltak csodálatosan szép napjaink, de annál többet csapkodtak a villámok a fejünk felett..." Aki tehát abban a kiváltságban részesült, hogy élete hajóját századunk viharai közepette kormányozhatta, néha próbákat kellett kiállnia.

Szabó János 1920-ban, ebben a hazánk számára végzetes, szomorú esztendőben, november 27-én látta meg a napvilágot az ötgyermekes család harmadik gyermekeként. A keresztségben a Szabó Kapisztrán János nevet kapta. A gyermekek Szabó Sándor és Hofhauser Ida frigyéből születtek.

Apai nagyapja szabómester, anyai nagyapja, Hofhauser Elek kiváló budai építőmester volt, akinek kőfaragó ősei valamikor a XVII. század végén, Buda visszafoglalását követően Bajorországból vándoroltak be hazánkba. Az építés és kőfaragás mestersége a családban apáról fiúra szállt.

Szülei házasságával két régi, becsületesen dolgozó iparos dinasztia egyesült. Édesapja azonban hamarosan elhagyta a családot, ettől kezdve édesanyja egyedül nevelte öt gyermekét, akik közül kettő még 12 éves kora előtt meghalt. Az édesanyának munkába kellett állnia, hogy gyermekeit eltarthassa. Tragikus sorsa, csodálatos anyai helytállása meghatározó élménye volt gyermekeinek.

* Elhangzott 80. születésnapján, 2000. november 27-én, a tiszteletére rendezett ünnepségen a Műegyetem dísztermében. Lapunk főszerkesztőjét e tanulmánnyal és szakirodalmi munkásságának közlésével köszönti a szerkesztőség. 
Szabó János a II. kerületi Királyi Egyetemi Katolikus Reálgimnáziumban kedvelte meg a matematikát, és célként a matematika-fizika tanári pályát jelölte meg. Az 1938-ban letett érettségi mindenben feljogosította erre, azonban a természetjárás hamarosan eltérítette ettől az iránytól, és a térképek hatása alá került. Ezért a geodézia iránti vonzalmától vezérelve beiratkozott a József Nádor Mủegyetem Kultúrmérnöki Karára.

Az egyetemen hamarosan kitűnt élénk érdeklődésével és szorgalmával. Egyike volt az évfolyam azon három hallgatójának, akik kitünőre vizsgáztak Oltainál. Ennek köszönhetően 1940-ben Oltai professzor ajánlására három egymást követő nyáron a budapesti városmérés szolgálatába állhatott. Érdeklődése egyre inkább a hídépítés mechanikai problémái felé fordult. Mihailich és Kossalka professzorok a legjobb hallgatóik között tartották számon. Olyannyira beleásta magát a Tartók statikája rejtelmeibe, hogy Vásárhelyi Mihály barátjával közösen példatárat szerkesztettek és adtak ki a tárgyból. Ugyancsak nagy hatást tettek rá „A hídépítés válogatott fejezetei" címủ kurzus előadói, Menyhárd István és Mistéth Endre, s ez arra indította, hogy még a diploma elött tervezőirodában helyezkedjék el.

A szerény mérnöki iroda, amelyet Sávoly Pál vezetett, a József körút 56. szám alatti bérház IV. emeletének egyik udvari lakásában volt. Hamarosan komoly feladatokat kapott. Az Árpád-híd margitszigeti lejárójának vasbeton szerkezete, vagy a MABI - ma Kútvölgyi - kórház vasbeton elemeinek tervezési munkái során a geodéziában szerzett precizitásának nagy hasznát vette: naphosszat pörgött a kézi tekerős „Facit” számológép a keze alatt, hogy a vasbeton szerkezetek kivitelezésének pontatlanságai elkerülhetők legyenek. Tervezési tapasztalatainak szorgos gyüjtögetése közben szerezte meg a diplomáját 1943-ban.

Ugyanez év őszén behívták katonának. Bevonult a szentendrei vasútépítő ezredhez. Itt kezdetben a Zirc és Dudar közötti vasútvonal tervezésén dolgozott, majd a háborús kárt szenvedett vasútállomány helyreállítása volt a feladata. 1945 májusában hadifogságba esett, két és fél évet töltött a Krím félszigeten, nem meszsze Jaltától. A jaltai építőipari vállalat mindenes mérnökeként építésvezetéssel bízták meg, a magyar hadifoglyok munkáját kellett megszerveznie. Nem volt könnyü feladat ezt úgy végezni, hogy hadifogoly honfitársai élete elviselhetőbbé váljék.

A hadifogság alatt egész további életét meghatározó sorsfordító ismeretekkel gazdagodott. Megfogalmazódott benne a vezérelv, amely aztán egész későbbi élete során irányította: az ember nem élhet úgy a társadalomban, hogy ne érezze szükségét valamiféle közös ügy iránti elkötelezettségnek.

A hadifogságból hazatérve a rombadőlt Budapest várta. Újból belevetette magát a múszaki tervezésbe. Számos megsérült és teljesen újjáépített épület tartószerkezeteinek tervezését végezte, egyre felelősebb beosztásban. 



1949-ben rövid időre az Építésügyi Minisztérium Iparoktatási Osztályának vezetője lett. Bekapcsolódott a Közlekedéstudományi Egyesület munkájába, és az Építők Szakszervezetében matematikát tanított a pallérképző tanfolyamokon. Még 1949-ben átkerült a Haditechnikai Intézetbe kutatónak, először polgári alkalmazottként, majd hivatásos tisztként. Itt anyagvizsgálattal foglalkozott, ami további mérnöki tevékenységére döntő befolyást gyakorolt. Nem foglalkozhatott sokáig a kedvelt kutatással, mert az 1950-ben szerveződő iparfejlesztési feladatok a köz szolgálatába állították: kérése ellenére megbízták a Közlekedési és Postaügyi Minisztériumban a Müszaki Tervezési Főosztály megszervezésével. Ekkor még 30 esztendős sem volt. Szervező munkája során egyre világosabbá vált előtte, hogy az építőiparban és a közlekedésben erőteljesebb és koncentráltabb munkára van szükség, a tervezésben és az irányításban egyaránt. Szervező munkája eredményeként a KPM tervező vállalatainál nagy tudású, kiváló szakembergárda alakult ki, és jó együttműködés jött létre olyan nagyszerü intézményekkel, mint az Út- és Vasúttervező, a Mélyépítési Tervező, vagy a Metró Tervező Vállalat.

1955-ben - minden kérése és tiltakozása ellenére - az akkor még egészen fiatal Város- és Községgazdálkodási Minisztériumba került csoportfőnöknek. Itt mindent elölről kellett kezdenie, viszont alkalma nyílt arra, hogy a kultúrmérnöki szakma újabb területeivel ismerkedjék meg: a vízellátás, csatornázás és szennyvízelvezetés feladataival. 


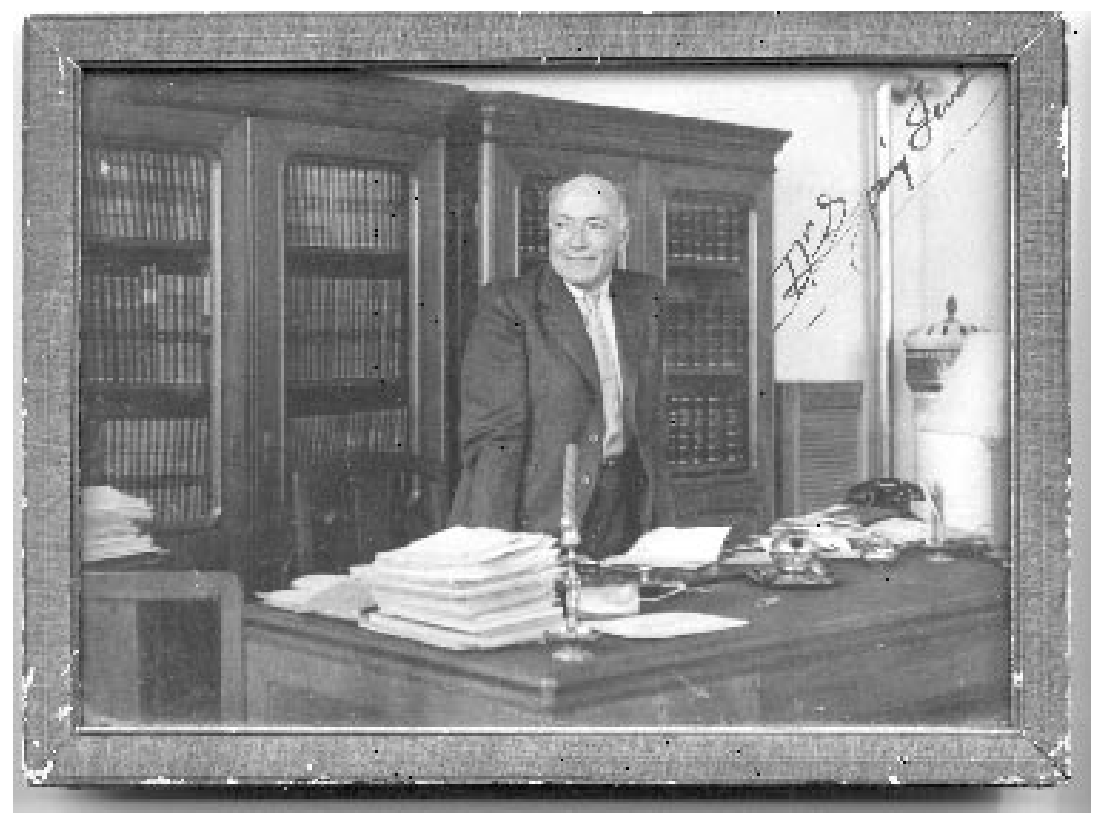

Amíg Szabó János közéleti pályafutása a sok kényszerü újrakezdés miatt több lokális koordinátarendszerrel jellemezhető, kutatói pályája egyetlen rendszerben írható le. A sors különös játéka talán, hogy élete meghatározó találkozása egy csodálatos emberrel egy tragédia nyomán jött létre, és kapcsolatuk ugyancsak tragédiával ért véget... 1951-ben egy hídépítési baleset okainak kutatása tartotta izgalomban a szakembereket, és egy addig nem ismert jelenségre hívta fel a figyelmet: a súlyos és nagyméretű szerkezeti elemek beemelés közben elveszthetik stabilitásukat, ami gyakran katasztrófához vezet. Ennek a problémának az elemzése során jutott arra a gondolatra, hogy felkeresi a Múegyetemen Egerváry Jenő matematika professzort. A találkozás elemi erővel hatott rá: amikor vázolta a problémát, Egerváry nem kért gondolkodási időt, hanem azonnal megfogalmazta azt az egyszerủ matematikai modellt, amellyel percek alatt ki lehetett számítani, hogy a felfüggesztett és kibillentett hídelem milyen helyzetében kerül instabil állapotba, amelyből már nincs visszaút, és progresszív összeomlás következik be.

Ez az intermezzo mély nyomokat hagyott benne, és matematikai kíváncsiságát végképp felcsigázta. A szakvélemény kidolgozása folyamán kapcsolatuk elmélyült, és Egerváry meghívta a tanszékére, hogy a numerikus matematika módszereiről tartson előadásokat.

1954-tôl kezdve tehát félállású adjunktusként dolgozott Egerváry mellett a mérnökkari Matematika Tanszéken. Nemcsak Egerváry zsenialitása és előrelátása, hanem az enyhülés szelei is azt kezdték susogni ekkoriban, hogy a kibernetika már nem amerikai áltudomány többé, így érdemes lesz a numerikus módszerekkel, és 
elsősorban a mátrixaritmetikával, ezzel a különlegesen kézenfekvő jelrendszerrel foglalkozni.

A számítástechnika hazánkban akkor még nem sejthető forradalmának előszele ugyanis már benne volt a levegőben. Ma már tudjuk, hogy Egerváry professzornak az 1953. január 5-i akadémiai felolvasó ülésen a mátrixfüggvények kanonikus előállításáról és alkalmazásáról elhangzott csodálatos előadása a numerikus mechanika hazai születésnapjának tekinthető. Szabó János is élvezettel merült bele az új diszciplínába, és egymás után születtek dolgozatai a mechanikai jelenségeket leíró differenciálegyenletek és a mátrixkalkulus kapcsolatáról.

Akkoriban nálunk még nem voltak programvezérlésü számítógépek, így számítási eredményeit kézi meghajtású számológéppel éjszakákon át, rettenthetetlen kitartással végezte. Aki vérbeli kutató, megérti, milyen feszítő kínokat áll ki az, akit ötleteinek kimunkálásában a körülmények gátolnak. Minden alkalmat megragadott tehát, vidéki autóutak során, értekezletek alatt, éjszakákon át otthon is dolgozott.

A sok kitartással járó, lopott időben végzett kutatómunka meghozta gyümölcsét, és az első tudományos megmérettetés 1956-ban be is következett, amikor megvédte kandidátusi értekezését.

Az 1956-os esztendő azonban egy másik, súlyosabb megmérettetés éve is volt. Ezt megelőzően - magas állami beosztásából fakadóan is - egyre növekvő gyakorisággal szerzett fájó benyomásokat, egyre kevésbé érezte a biztonságát annak a politikának, amely mellé a háború után, a hadifogságból hazatérve lehorgonyozta hajóját. Ezért nem érezte teljesen váratlannak, ami 56 őszén bekövetkezett. Magát a Város- és Községgazdálkodási Minisztériumot az év végén likvidálták, és a 400 fős cég megszüntetésének nem könnyü feladatával bízták meg, míg végül állás nélkül maradt ő is. Bejárt a Matematika Tanszékre, majd később az UVATERV Híd-irodájában kapott állást. Újból Sávoly Pál keze alá került, akinek magánirodájában 15 évvel korábban mérnöki pályafutása elkezdődött, és aki azután is atyai szeretettel figyelte sorsát. Lehetővé tette számára, hogy olyan feladatokkal foglalkozzon, amelyek kutatói érdeklődésével összhangban állnak. Bár jól érezte magát, ekkor már nem tagadhatta meg kutatói önmagát: váltania kellett, mert úgy érezte, kutatómérnökként nem akar a konstruktőrök terhére lenni, és munkája egy kutatóintézetben gyümölcsözőbb lehet. 1958-ban ajánlatot kapott az Építéstudományi Intézettől, ahol később igazgatóhelyettes, majd igazgató lett.

Az 1958-as esztendő örökké emlékezetes marad a számára. Ebben az évben történt az a tragikus esemény, amelynek nyomán mesterétől, Egerváry professzortól örökre búcsút kellett vennie. Egy soha meg nem bocsátható és helyre nem hozható félreértés Egerváry professzort olyan ügybe keverte, amelyben alapvető ártatlansága bizonyára hamar kiderült volna. A méltatlan és megalázó helyzetet e talpig férfi nem tudta elviselni, és önkezével véget vetett életének. Vele az az ember 
szállt sírba, akitől Szabó János a legtöbbet tanulta, és akinek termékenyítő hatása Szabó János pályafutásán is túlmutat: közvetve bár, de generációkon át kifejti hatását.

A Matematika Tanszék után az I. Hídépítési Tanszékre került, majd 1960-ban docensi kinevezést kapott a Mechanika Tanszékre.

Időközben az ÉTI-ben igazgató lett, az építőipari kutatás nehézségeivel küszködött. Számos tanulmány született ott ebben az időben, sok kitúnő kolléga közremüködésével. Egy 1958-as kormányhatározat értelmében kidolgozásra került az első 15 éves lakásfejlesztési terv, amelyben az ÉTI-nek is része volt a blokkos építési technológia kidolgozásával. Ugyanebben az időben nagydoktori disszertációjának anyagával is jelentősen előrehaladt, változatlanul az eredeti csapásvonalon: a numerikus módszerek mérnöki alkalmazása területén. Pályafutásának az ÉTI-ben véglegesen - doktori terveinek átmenetileg - egy magas szintủ látogatás vetett véget. Felkérést kapott 1961-ben az Építésügyi Minisztérium miniszterhelyettesi posztjára. A feladat a hazai építés iparosítása volt. Ellentmondásokkal terhes, nagyon nehéz négy év következett. S mivel gúzsbakötve táncolni igen nehéz, a megbízatás 1965-ben saját kezdeményezésre véget ért. Ettől kezdve teljes munkaidőben dolgozott a Mechanika Tanszéken. Ez az időszak volt hazánkban a számítástechnika hőskora, amelyben úttörő szerepet vállalt, mert korábbi kutatásainak gyümölcse ekkorra fordult termőre. Közben történt egy nagyon fontos esemény: 1964 nyarán megvédte nagydoktori disszertációját, és a következő évben egyetemi tanárrá nevezték ki.

Oroszlánrészt vállalt tantárgyaink és kutatási témáink elkerülhetetlen reformjában: a számítógépes módszerekre való áttérésben, amelyben elsősorban a fiatalokra támaszkodott. Mi, akik ebben részt vettünk, fél szavakból értjük egymást, mi tudjuk, mi rejlik a szó mögött: Ural-2!

Mátrixokkal keltünk és feküdtünk, invertáltunk, konvertáltunk, transzformáltunk, transzponáltunk, linearizáltunk, diagonalizáltunk, adjungáltunk, permutáltunk, spektrál-felbontottunk, sajátértéket kerestünk, programoztunk és futtattunk. Programoztunk gépi kódban, félautokódban, autokódban, és folyton hibát kerestünk, szintaktikait és szemantikait, és újból és újból futtattunk és programoztunk, és nem adtuk fel, ha százszor is nem futott le a program. Íróasztalunkon toronyban álltak a lyukszalagok és a lyukkártyák, meg a perforált szélü protokollok. Csodálatos, termékeny idők voltak azok, mert egy teljesen új világ bontakozott ki előttünk: a numerika varázslatos világa. Ezt az időszakot a tanszék aranykorának tekinthetnénk, de lehet, hogy ezt csak az elfogultság mondatná velünk...

Ebben az időben került sor a korábban szerencsétlenül kettéválasztott BME és ÉKME újraegyesítésére. Ekkor Csáki Frigyes rektor a tudományos rektorhelyettesi feladattal bízta meg, amelyet örömmel vállalt el. Úgy tủnik tehát, hogy révbe ért a Mủegyetemen, de nem sokáig tartott ez a nyugodt, sikeres kutatási időszak. 
1968 táján ugyanis az új mechanizmus szelei kezdtek lengedezni, és egy újabb magas szintủ megkeresés nyomán a felívelő tudós pálya megint gellert kapott. Ezúttal jó hosszú időre. 1968 tavaszán kezdődött államigazgatási munkássága utolsó 15 esztendeje, élete legellentmondásosabb szakasza: az Építésügyi és Városfejlesztési Minisztériumban miniszterhelyettesként, majd államtitkárként. Ettől kezdve a könnyüszerkezetes építési mód apostolának hajója Scylla és Charybdis szirtjei között hányódott, megosztva erejét az Egyetem és a Minisztérium, a nyugat-európai és a moszkvai házgyárak között... A megbízáskor 48 éves volt. Ereje teljében, nagy tapasztalatokkal a tarsolyában, az 1968-as változásokban rejlő lehetőségekben bízva látott hozzá egy új múszaki fejlesztési koncepció kialakításához. 1983ban, 63 évesen, sok szép, de még több keserü tapasztalattal gazdagodva köszönt le posztjáról, és jött végleg vissza közénk.

Nevéhez füződik a mérnökmatematikus szakmérnöki szak létrehozása a 60-as évek végén. A képzéshez megnyerte más karok kiemelkedő oktatóit is előadóként. Itt kaptak erős elméleti alapot és a szakmában való alkalmazási lehetőségekre kitekintést a kar akkori TMB-ösztöndíjasai és a kutatásban elmélyülni kívánó fiatal oktatók. Karunk mai egyetemi tanárai és docensei közül is többen az itt kapott útravalóval indultak el a tudományos pályán, és az itt kidolgozott tárgyak adták meg az alapot a 90-es évek elején induló doktori programokhoz.

1970-ben kiemelkedő tudományos munkássága alapján a Magyar Tudományos Akadémia levelező, majd 1979-ben rendes tagjává választotta. Az MTA Műszaki
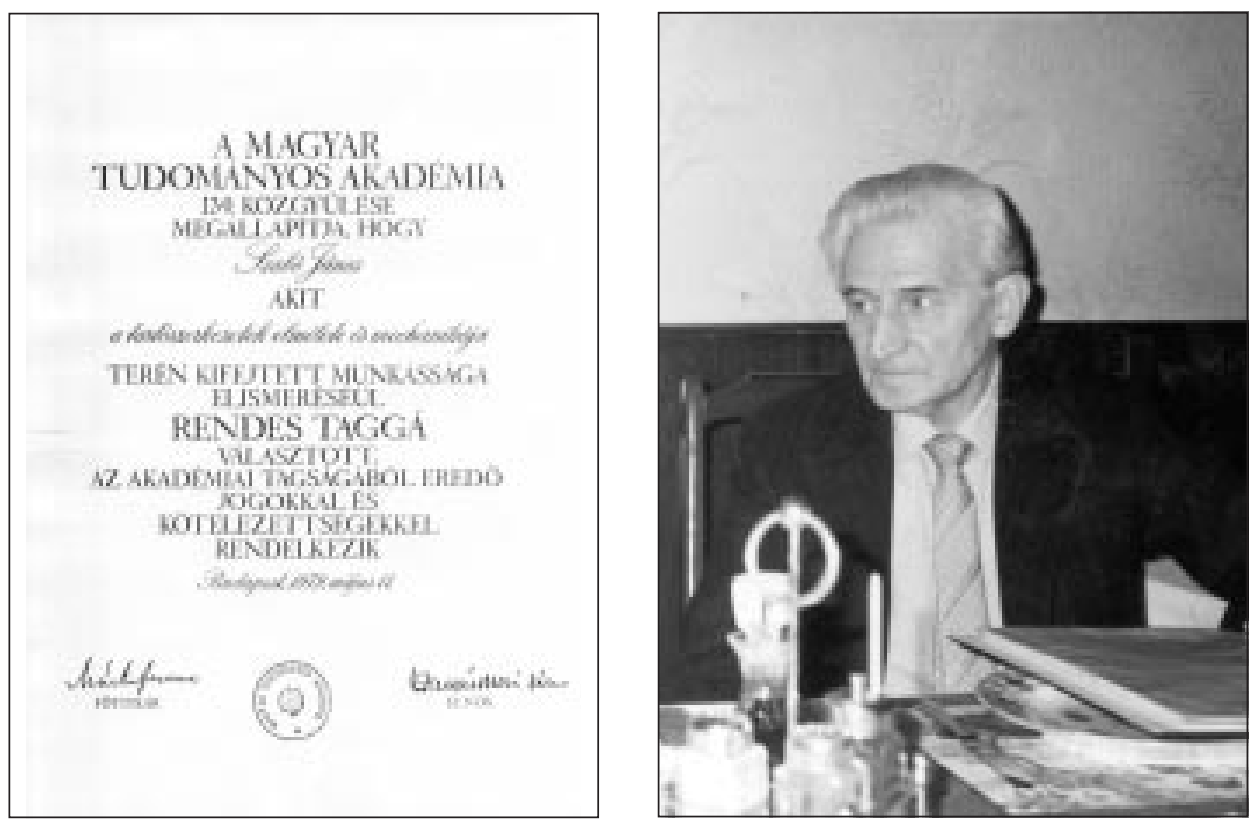
Tudományok Osztálya elnökhelyettesi és a Műszaki Mechanikai Bizottság elnöki tisztét is ellátta. Hosszú ideig, egészen a megszűnéséig a Tudományos Minősítő Bizottság elnöke volt.

Főbb kutatási területén, a magas- és hídépítési szerkezetek mechanikája, a rúdszerkezetek állapotváltozása és stabilitásvizsgálata, a hálók és kábelszerkezetek számítása területén tudományos eredményeit magyar és idegen nyelven 6 szakkönyvben, több mint 100 szakcikkben és számos előadáson ismertette. 1971-ben jelent meg Roller Bélával közösen írt nagysikerú könyve, mindannyiunk bibliája: a Rúdszerkezetek elmélete és számitása. Ez a könyv később németül is megjelent.
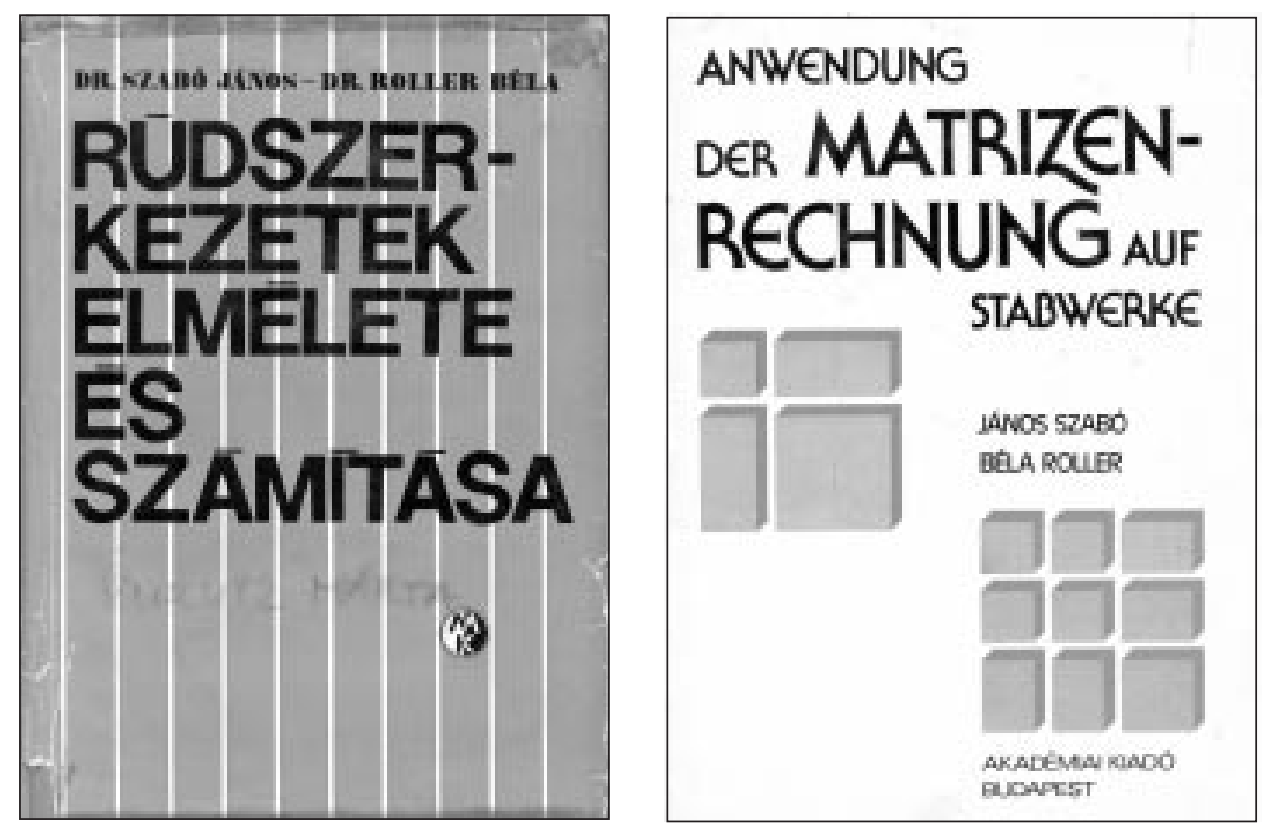

Számos magas állami kitüntetése mellett szakmai kitüntetései között az 1959ben kapott Jáky Emlékérmet, az 1973-ban kapott Alpár Érmet, az 1975-ben kapott BME Emlékérmet és az 1985-ben kapott Állami Díjat említhetjük.

November elején, a Tudomány Napján vehette át az Arany János Közalapítvány „Tudományért Nagydíj”-át kimagasló iskolateremtő tevékenységéért és a tudományos utánpótlás területén kifejtett kiemelkedő munkájáért.

Nyugdíjasként napjainkban is aktívan dolgozik a Tanszéken. Ma is programokat ír, dolgozatokat publikál, tanácsaival segíti a tanszéki kutatómunkát, és részt vesz a tudományos közéletben. Bár állami feladatai miatt tanszékvezetô sohasem 
lehetett, kapcsolata a tanszék vezetőivel mindig nagyon harmonikus volt. 1996ban lett egyetemünk professzor emeritusa.

Sokáig törtem a fejem, hogyan tudnám befejezésként egészen tömören összegezni ennek a szép és gazdag életpályának a lényegét. A megoldás a régi emlékek, a hosszú együtt töltött munka során született üzenő cédulák, iratok, levelek közti rendezgetés során adódott. Van egy levelem tőle, amelyet különös szeretettel örzök emlékeim között. Ennek a levélnek a mottója, egy Arany-idézet helyettem beszél. Mindennél jobban jellemzi azt az embert, akit most mindannyian köszönteni gyültünk egybe:

\author{
„Legnagyobb cél pedig \\ itt a földi létben \\ EMBER lenni mindég, \\ minden körülményben."
}


